\title{
ЦИТОГЕНЕТИЧЕСКИЕ НАРУШЕНИЯ И ОСОБЕННОСТИ ВАРИАБЕЛЬНОСТИ СЕРДЕЧНОГО РИТМА У ГОРНОРАБОЧИХ МУРМАНСКОЙ ОБЛАСТИ
}

\section{Пожарская В.В., Мартынова А.А., Петрашова Д.А.}

Научно-исследовательский иентр медико-биологических проблем адаптации человека в Арктике КНЦ PAH, Anamumbl, vika_pozharskaja@mail.ru

Мурманская область является регионом с развитыми горнодобывающей, энергетической, металлургической отраслями промышленности. В связи с этим, на организм жителей региона влияют не только факторы, связанные с климатическими особенностями среды (полярная ночь, полярный день), географическое положение (зона авроральных явлений) и т. п., но и различные техногенные токсиканты, попадающие в окружающую среду в результате разработки различных месторождений полезных ископаемых и дальнейшего их использования в различных отраслях промышленности. Особенно это касается работников горнорудного производства, чья профессиональная деятельность связана с интенсивным воздействием факторов производственной среды и трудового процесса, обусловливающих высокий риск травматизма и нарушения здоровья. Особый вклад в здоровье работников горнорудного производства вносят специфические условия труда, связанные с характером добычи руды и ее составом, в частности, в отдельных случаях, содержащих природные примеси радионуклидов $[4 ; 7 ; 6]$.Так как влияние экстремальных климатогеографических условий Арктического региона оказывает существенное влияние на здоровье проживающих на данной территории людей $[1 ; 5 ; 3]$, необходимо изучать механизмы сохранения, формирования и укрепления здоровья в процессе развития и реализации потенциала человека с учетом генетических, физиологических, психологических и других особенностей различных групп населения.

Одним из методов оценки и контроля цито- и генотоксических эффектов, проявляющихся в результате воздействия специфических условий труда и особенностей места проживания человека в районах Крайнего Севера и местностях, приравненным к данным районам является микроядерный тест на лимфоцитах периферической крови и буккальном эпителии. Функциональное состояние организма человека можно оценить с помощью вариабельности сердечного ритма (ВСР), которая позволяет выявить влияние вегетативной нервной системы (BНC) на сердечно-сосудистую систему, которая в свою очередь является индикатором эффективности адаптационных процессов в организме человека [2].

В 2013-2015 гг. были проведены комплексные исследования, направленные на выявление степени воздействия особенностей производственной среды на организм человека. Исследовались цито- и генотоксические эффекты на клеточном уровне, а также отклонения в функциональном состоянии организма в зависимости от условий труда работников горнорудного производства (Мурманская область), связанного с подземной добычей и обогащением лопаритовой руды, содержащей естественные примеси радионуклидов. Исследования проводились в рамках ежегодного профилактического осмотра и включали в себя забор биоматериала (венозная кровь, соскоб буккального эпителия с внутренней стороны щеки) для цитогенетического анализа и измерение ВСР у работников горнорудного производства мужского пола (391 человек), средний возраст которых составил $42.9 \pm 0.6$ лет. Группа сравнения была сформирована из 140 мужчин со средним возрастом $39.3 \pm 1.7$ лет, не работающих в условиях, связанных с производственной вредностью.

Установлено, что на частоту цитогенетических нарушений основное влияние оказывают производственный стаж и возраст работников. В связи с этим, для исключения вклада возрастного фактора, наиболее целесообразно проводить оценку цито- и генотоксических эффектов природных источников ионизирующего излучения с помощью микроядерного теста на лимфоцитах крови и буккальном эпителии на возрастной группе 20-30 лет. Для этой группы характерны меньший уровень патологий, накопленных с возрастом, и более низкая вероятность смены места работы по состоянию здоровья или за счет карьерного роста [8; 9].

Проведенные исследования показали, что цитогенетические особенности в лимфоцитах периферической крови, вызванные облучением смешанными источниками ионизирующего излуче- 
ния природного происхождения, у лиц, подверженных данному воздействию в период работы, проявляются в более высокой частоте двуядерных лимфоцитов с микроядрами относительно одновозрастной группы лиц, не имевших в анамнезе факторов радиационных воздействий. Учет всех типов лимфоцитов в культурах цельной крови показал, что в крови контрольной группы число полиядерных клеток меньше, чем у группы добровольцев подверженных хроническому облучению, что свидетельствует об уменьшении продолжительности клеточного цикла у горняков [10]. Возрастание частоты многоядерных клеток в группе горняков, по сравнению с группой сравнения, также может свидетельствовать о воздействии ионизирующей радиации на процесс цитокинеза, нарушение которого может приводить к появлению многоядерных клеток.

В первые годы трудовой деятельности возрастает общая частота цитогенетических нарушений в клетках буккального эпителия, в частности, растет частота встречаемости клеток с микроядрами, а также увеличивается частота встречаемости клеток с признаками нарушения пролиферации. Эти изменения происходят на фоне снижения интенсивности апоптоза и увеличения скорости обновления буккального эпителия, которое проявляется в возрастании частоты встречаемости клеток буккального эпителия с конденсацией хроматина ядра. Таким образом, у горнорабочих в первые несколько лет трудовой деятельности клетки буккального эпителия с нарушениями элиминируются с меньшей скоростью и мы, вероятно, наблюдаем накопительный эффект. Полученные результаты согласуются с литературными данными о том, что у людей цикл адаптивной перестройки в новой экологической и климатической зоне с субэкстремальными условиями длится 2-3 года [11]. Следовательно, начало работы в условиях горнорудного производства можно отнести к новому стрессовому воздействию на организм, в том числе и на клеточном уровне.

Оценка кардиогемодинамических показателей рабочих занятых на подземных работах показала повышение частоты сердечных сокращений (ЧСС) и артериального давления, что на фоне снижение временных показателей (SDNN, RMSSD, ms), свидетельствует о напряжении регуляторных систем организма и подавлении активности автономного контура регуляции сердечного ритма (СР). Организм, реагируя на воздействие со стороны окружающей среды, выбрасывает химические медиаторы - в частности катехоламины, способствующие увеличению частоты сердечных сокращений и артериального давления, что приводит к избыточному центральному контролю сердечного ритма (CP) и артериального давления. Повышение ЧСС, вместе со снижением мощности низких (LF, ms $\left.{ }^{2}\right)$ и высоких $\left(\mathrm{HF}, \mathrm{ms}^{2}\right.$ ) частот у горняков, так же свидетельствует об истощении вегетативной регуляции миокарда и увеличении нагрузки на сердечно-сосудистую систему. Увеличение вклада очень низкочастотной компоненты (VLF, \%), являющуюся индикатором энергодефицитных состояний, в суммарную мощность спектра (ТР) у горняков, может свидетельствовать о истощении энергетических ресурсов организма, и нарушении вегетативного баланса. Подтверждением этому, является снижение мощности всех спектральных характеристик CP (TP, HF, LF, VLF, ms ${ }^{2}$ ), что приводит к смещению вегетативного баланса (LF/HF) в звеньях регуляции АНC сердечного ритма в сторону усиления симпатических и нейрогуморальных влияний. В результате чего усиливается напряжение регуляторных механизмов (SI, у.е.), что отражается на снижении адаптационного потенциала. Следовательно, можно предположить, что затраты организма на физиологическую адаптацию к тяжелым физическим условиям труда усиливают тенденцию развития дизадаптивных процессов. Сравнение влияния возрастных и производственных условий на ВСР показало, что с возрастом влияние производственных условий труда на ВСР снижается, преобладает влияние возрастных изменений работы СР. Таким образом, полученные результаты свидетельствуют о напряжении механизмов регуляции ВСР у горняков, что может быть следствием комплексного воздействия производственных факторов труда. Снижение высокочастотных волн (HF), увеличение низкочастотных (LF) и «очень» низкочастотных (VLF) компонент спектрального диапазона сердечного ритма характеризует преобладание центральной регуляции ВСР за счет доминирующего влияния симпатического звена, что отражает истощение механизмов оптимальной физиологической регуляции ВСР.

Таким образом, перспективность освоения Арктики позволяет предположить, что и в дальнейшем в Мурманской области с каждым годом будут увеличиваться масштабы хозяйственной де- 
ятельности человека, при которой, вероятно, будут увеличиваться объемы трудовых ресурсов, задействованных в проведении различных работ, постоянно или временно проживающих на территории региона. Наличие экстремальных климатогеографических условий Арктического региона, оказывающих существенное влияние на здоровье проживающих на данной территории людей, делает необходимым комплексные исследования здоровья населения Севера. В результате проведенных цитогенетических исследований установлено, что на частоту встречаемости цитогенетических нарушений работников одного из предприятий горнорудного производства Евро-Арктического региона основное влияние оказывают производственный стаж и возраст работающих в данных условиях, изменение процессов цитокинеза и скорости пролиферации клеток также зависит от вида трудовой деятельности человека. Условия труда также проявляются и в вегетативной дисфункции в регуляции ВСР. Проведенные исследования показывают необходимость проведения дальнейших научных работ по выявлению механизмов адаптации человека к условиям проживания и труда, что позволит сформулировать рекомендации по улучшению качества жизни населения, повышению эффективности труда и профессиональному долголетию в суровых условиях Севера.

\section{Благодарности}

Авторы выражают искреннюю благодарность за помощь в организации исследований д.б.н. Наталье Константиновне Белишевой и главному врачу ГОБУЗ Ловозерская ЦРБ Ольге Борисовне Цыпышевой.

\section{Литература}

1. Анисимов В.Н., Виноградова И.А., Букалев А.В., Борисенков М.Ф., Попович И.Г., Забежинский М.А. Панченко А.В., Тындык М.Л., Юрова М.Н. Световой десенхроз и риск злокачественных новообразований у человека: состояние проблемы // Вопросы онкологии. 2013. Т. 59. № 3. С. 302-313.

2. Баевский Р.М., Берсенева А.П., Лучицкая Е.С., Слепченкова И.Н., Черникова А.Г. Оценка уровня здоровья при исследовании практически здоровых людей. М.: Слово. 2009. 100 с.

3. Белишева Н.К. Вклад высокоширотных гелиогеофизических агентов в заболеваемость населения ЕвроАрктического региона // Вест. Ураль. мед. академ. науки. 2014. № 2 (48). С. 5-11.

4. Белишева Н.К., Мельник Н.А., Балабин Ю.В., Буркова Т.Ф., Талыкова Л.Ф. Вклад техногенных и природных источников ионизирующего излучения в структуру заболеваемости населения Мурманской области // Вестник КНЦ РАН. 2013. № 4. С. 9-28.

5. Белишева Н.К., Петров В.Н. Проблема здоровья населения в свете реализации стратегии развития Арктической зоны Российской Федерации // Тр. КНЦ РАН. Апатиты. 2013. Вып. 4. С. 151-173.

6. Мартынова А.А., Михайлов Р.Е., Пряничников С.В., Белишева Н.К. Особенности вариабельности сердечного ритма у работников горнорудного производства в Мурманской области // Экология человека - Архангельск. 2017. № 3. С. 31-37.

7. Петрашова Д.А., Белишева Н.К., Пелевина И.И., Мельник Н.А., Зользер Ф. Генотоксические эффекты в буккальном эпителии горняков, работающих в условиях облучения природными источниками ионизирующего излучения // Изв. Самарского научного центра Российской академии наук. 2011. Т. 13. № 1( 7). С. 1792-1796.

8. Петрашова Д.А., Пожарская В.В. О проблеме анализа многофакторного воздействия в цитогенетических исследованиях на примере микроядерного теста в клетках буккального эпителия человека // Тр. XII Всероссийской (с международным участием) научной школы «Математические исследования в естественных науках», посвящённой 100-летию со дня рождения д.г.-м.н. А.Б. Вистелиуса. Апатиты, 26-27 октября 2015 г. Апатиты: Изд-во К \& М. 2015. С. 189-197.

9. Пожарская В.В., Петрашова Д.А. Роль особенностей учета цитогенетических аномалий при оценке воздействия генотоксических факторов окружающей среды на примере лимфоцитов крови человека // Tp. XII Всероссийской (с международным участием) научной школы «Математические исследования в естественных науках», посвящённой 100-летию со дня рождения д.г.-м.н. А.Б. Вистелиуса. Апатиты, 26-27 октября 2015 г. Апатиты: Изд-во К \& М. 2015. С. 197-205.

10. Пожарская В.В., Петрашова Д.А. Цитогенетические нарушения в лимфоцитах периферической крови у горнорабочих Мурманской области в возрасте до тридцати лет // Вест. науки и образования. 2016. № 10 (22). С. 15-19.

11. Физиология человека / под ред. В.М.Покровского, Г.Ф.Коротько. М. 2003. 656 с. 